\title{
VARIASI KELOMPOK MAKANAN PENDAMPING AIR SUSU IBU DAN STATUS GIZI ANAK USIA 6-23 BULAN DI KECAMATAN MINGGIR, KABUPATEN SLEMAN, DAERAH ISTIMEWA YOGYAKARTA
}

\author{
VARIATION COMPLEMENTARY FOOD GROUP OF BREASTMILK AND \\ NUTRITION STATUS CHILDREN AGE 6-23 MONTHS IN MINGGIR \\ DISTRICT, DISTRICT SLEMAN, REGIONAL ISSUES YOGYAKARTA
}

\author{
Wulan Ningrum, Th Ninuk Sri Hartini, Tjarono Sari \\ Jurusan Gizi Politeknik Kesehatan Kementerian Kesehatan Yogyakarta
}

\begin{abstract}
ABSTRAK
Pada usia enam bulan, bayi mulai diberikan Makanan Pendamping Air Susu Ibu (MPASI). Anak menginjak usia lebih dari 6 bulan maka anak harus diberikan makanan tambahan. Jika anak tidak memperoleh cukup gizi dari MP-ASI, akan mengalami gangguan pertumbuhan dan kurang gizi. Usia tersebut merupakan periode emas sekaligus kritis dalam proses tumbuh kembang anak, baik fisik maupun kecerdasan. Makanan Pendamping Air Susu Ibu yang bervariasi diperlukan untuk memenuhi kebutuhan gizinya. Asupan yang baik akan menjadikan anak memiliki status gizi yang baik pula. Tujuan adalah mengetahui variasi kelompok MP-ASI dan status gizi anak usia 6-23 bulan di Kecamatan Miggir.Penelitian dilakukan pada 5 desa di Kecamatan Minggir.Sampel berjumlah 194 subyek. Penilaian variasi dilihat dari 3 komponen yaitu banyaknya bahan yang dikonsumsi, konsumsi ASI dan susu formula. Variasi dikelompokkan menjadi 3 yaitu rendah (nilai 0-2.9), sedang (nilai 3-3,9), dan tinggi (nilai 4-5). Variasi kelompok MP-ASI paling banyak pada kategori sedang yaitu $95(49,0 \%)$ anak serta status gizi paling banyak adalah gizi baik dan gizi lebih yaitu $169(87,1 \%)$. Asupan makan yang dinilai dengan variasi kelompok MP-ASI berpengaruh pada status gizi anak.Semakin rendah variasi Makanan Pendamping Air Susu Ibu maka semakin tinggi persentase gizi buruk dan gizi kurang.
\end{abstract}

Kata kunci : usia 6-23 bulan, variasi kelompok MP-ASI, status gizi, Yogyakarta.

\begin{abstract}
At the age of six months, babies begin to be given complementary foods. The children more than 6 months, should be given extra food. If the child are not have enough about nutrition from complementary foods, it will result in growth disorders and malnutrition. It is the golden period at once critical in the growth process of children, both physical and intelligence.Complementary foods must be come from different food to sufficient the nutritional needs. Good intake will make children have a good nutritional status anyway.Objective to identification of variation complementary food groups and nutritional status of children 6-23 months of age in Minggir.The sample was numbered 194 subjects. Assessment variation views of three components, namely the amount of materials consumed, consumption of breast milk and formula. Variations are grouped into 3, there are lower (grades 0-2.9), intermediate (grades 3 to 3.9), and high (grades 4-5). Variation complementary foods group most a lot on the medium category that is $95(49,0 \%)$ a son as well as nutritional status the most is nutrition good and nutrition more that is 169 ( $87,1 \%)$. Food intake were assessed by variation complementary foods groups affects the nutritional status of children. The lower variation of complementary foods that will make percentage of malnutrition higher.
\end{abstract}

Key words : 6-23 months of age, variation complementary food groups, nutritional status, Yogyakarta 


\section{PENDAHULUAN}

Status gizi adalah keadaan tubuh yang merupakan akibat dari konsumsi makanan dan penggunaan zat gizi tersebut yang kemudian dibagi menjadi 4 klasifikasi yaitu gizi buruk, gizi kurang, gizi baik, dan gizi lebih (Istiany dan Rusilanti, 2013). Masalah gizi masih terdapat di Indonesia, seperti prevalensi gizi kurang pada balita $(\mathrm{BB} / \mathrm{U}<-2 \mathrm{SD})$ memberikan gambaran yang fluktuatif dari 18,4 persen (2007) menurun menjadi 17,9 persen (2010) kemudian meningkat lagi menjadi 19,6 persen (tahun 2013). Secara nasional, prevalensi berat-kurang pada tahun 2013 adalah 19,6\%, terdiri dari $5,7 \%$ gizi buruk dan $13,9 \%$ gizi kurang. Jika dibandingkan dengan angka prevalensi nasional tahun 2007 (18,4 $\%)$ dan tahun $2010(17,9 \%)$ terlihat meningkat. Perubahan terutama pada prevalensi gizi buruk yaitu dari $5,4 \%$ tahun 2007 , 4,9\% pada tahun 2010, dan 5,7\% tahun 2013 . Sedangkan prevalensi gizi kurang naik sebesar 0,9\% dari 2007 dan 2013 (Kemenkes RI, 2013)
Status gizi dipengaruhi oleh dua hal utama yaitu makanan yang dikonsumsi dan derajat kesehatan,

konsumsi makanan dipengaruhi pola konsumsi keluarga dan pola distribusi makanan antar anggota keluarga. Jika asupan makanan yang dikonsumsi tidak bisa memenuhi kebutuhan maka hal itu akan berdampak pada status gizi dimasa depan yaitu status gizi kurang bahkan status gizi buruk(Aritonang, 2012).

Anak usia 0-23 bulan atau yang sering disebut dengan baduta (balita dibawah dua tahun) merupakan makhluk yang sangat peka dan halus. Pertumbuhan dan perkembangan salah satunya dipengaruhi oleh pola pemberian makanan.Makanan utama balita yaitu Air Susu Ibu (ASI) sehingga perlu dipersiapkan sebelum bayi lahir.Setelah usia 6 bulan, balita sangat membutuhkan makanan tambahan untuk tumbuh dan menjadi lebih aktif. Air Susu Ibu (ASI) saja tidak cukup untuk memenuhi nutrisinya. Dengan demikian, makanan tambahan diberikan untuk mengisi kesenjangan antar kebutuhan nutrisi total pada balita dan jumlah 
yang didapatkan dari ASI (Hayati, 2009).

Pada usia enam bulan, bayi mulai diberikan makanan pendamping Air Susu Ibu (MP-ASI), sebagian besar anak tidak mendapat MP-ASI dalam jumlah yang cukup baik dari segi kualitas maupun kuantitas serta jenis makanan yang beraneka ragam. Jika balita 6-23 bulan tidak memperoleh cukup gizi dari MP-ASI, maka akan mengakibatkan gangguan pertumbuhan dan kurang gizi. Oleh karena itu untuk mengatasi masalah kekurangan gizi maka diperlukan perbaikan pada kualitas maupun kuantitas MP-ASI (Kemenkes RI, 2010).

Variasi bahan makanan pada bayi penting karena tidak ada satupun makanan yang cukup untuk kebutuhan bayi, variasi bahan makanan yang diberikan sejak bayi akan diingat sampai dewasa, makanan yang diberikan harus sesuai dengan kemampuan pencernaan anak, mempunyai keawetan yang tinggi, biaya produksi terjangkau, mudah diproduksi secara massal dan aman (Proverawati dan Kusumawati, 2010)
Kecamatan Minggir merupakan salah satu Kecamatan di Kabupaten Sleman. Balita di Kecamatan minggir pada tahun 2014 berjumlah 2.006 dengan presentase status gizi dengan indeks berat badan menurut umur yaitu gizi buruk 1\%, gizi kurang 6,18\%, gizi baik 89,28\%, dan gizi lebih 3,54\% (Dinkes Sleman, 2014)

Pada penelitian Rochimiwati, Mas'ud dan Giringan (2013) di Tana Toraja mengatakan bahwa 50\% dari 18 anak diberikan MP-ASI dalam bentuk makanan pokok saja, yang berarti anak hanya mendapatkan zat gizi karbohidrat saja. Sedangkan untuk masa pertumbuhannya, anak memerlukan protein dan zat gizi lainnya yang mendukung pertumbuhan dan status gizinya.Berdasarkan hal tersebut peneliti tertarik untuk melihat variasi jenis MP-ASI dan status gizi pada anak usia 6-23 bulan di Kecamatan Minggir (Hikmawati dan Jayanti, 2013).

\section{METODE}

Jenis penelitian ini adalah dengan design cross sectional. Subyek penelitianadalah anak usia 6-23 
bulan di Kecamatan Minggir pada bulan Oktober 2015. Jumlah sampel yang memenuhi syarat penelitian sejumlah 194 anak.

Variabel bebas penelitian ini adalah variasi kelompok Makanan Pendamping Air Susu Ibu sedangkan variabel terikat adalah status gizi berdasarkan indeks BB/U. Analisis yang digunakan adalah analisis deskriptif

\section{HASIL DAN PEMBAHASAN}

\section{KARAKTERISTIK SUBYEK}

Subyek penelitian berjumlah 194 balita. Karakter subyek dalam penelitian ini adalah kelompok usia anak dan jenis kelamin.

Tabel 1. Karakteristik Subyek berdasarkan Usia dan Jenis Kelamin

\begin{tabular}{|c|c|c|}
\hline Karakteristik Subyek & $\mathrm{n}$ & $\%$ \\
\hline \multicolumn{3}{|l|}{ Usia anak (bln) } \\
\hline $6-8$ & 48 & 24,7 \\
\hline $9-11$ & 34 & 17,5 \\
\hline $12-23$ & 112 & 57,7 \\
\hline \multicolumn{3}{|l|}{ Jenis Kelamin } \\
\hline Laki-laki & 98 & 50,5 \\
\hline Perempuan & 96 & 49,5 \\
\hline$\sum$ & 194 & 100 \\
\hline
\end{tabular}

Berdasarkan Tabel 1, dapat diketahui bahwa subyek penelitian didominasi oleh anak laki-laki yaitu sebanyak $98(50,5 \%)$ dan anak perempuan sebanyak 96 $(49,5)$ anak. Usia anak paling banyak adalah anak berusia 12-23 bulan yaitu sebanyak $112(57,7 \%)$ anak, usia 9-11 bulan sebanyak 34 (17,5\%) anak, dan usia 6-8 bulan sebanyak $48(24,7 \%)$ anak.

\section{KARAKTERISTIK RESPONDEN}

Responden dari penelitian ini adalah ibu anak yang berusia 6-23

dilihat dari usia Ibu, pendidikan, dan pekerjaan.

Tabel 2. Karakteristik Responden berdasarkan Usia, Pendidikan, dan Pekerjaan

\begin{tabular}{|c|c|c|}
\hline Karakteristik Responden & $\mathrm{n}$ & $\%$ \\
\hline \multicolumn{3}{|l|}{ Usia Ibu (th) } \\
\hline$<20$ & 5 & 2,6 \\
\hline $20-35$ & 145 & 74,7 \\
\hline$>35$ & 44 & 22,7 \\
\hline \multicolumn{3}{|l|}{ Pendidikan Ibu } \\
\hline Dasar & 39 & 20,1 \\
\hline Menengah & 109 & 56,2 \\
\hline Tinggi & 46 & 23,7 \\
\hline \multicolumn{3}{|l|}{ Pekerjaan Ibu } \\
\hline Ibu Rumah Tangga & 149 & 76,8 \\
\hline Bekerja & 45 & 23,2 \\
\hline$\sum$ & 194 & 100 \\
\hline
\end{tabular}


Responden paling banyak berusia 20-

VARIASI

KELOMPOK

35 th yaitu sebanyak $145(74,7 \%)$

MAKANAN PENDAMPING AIR

orang dengan pendidikan paling SUSU IBU

banyak yaitu pendidikan menengah yaitu $109(56,2 \%)$ orang dan mayoritas pekerjaannya adalah Ibu Rumah Tangga yaitu sebanyak 149 $(76,8 \%)$.

Variasi kelompok Makanan

Pendamping Air Susu Ibu didapat dengan menilai tiga komponen yaitu banyaknya bahan makanan yang dikonsumsi dari tujuh kelompok bahan makanan, konsumsi susu formula, dan Air Susu Ibu.

Tabel 3. Variasi Kelompok Makanan Pendamping Air Susu Ibu berdasarkan Jenis Kelamin dan Kelompok Usia

\begin{tabular}{|c|c|c|c|c|c|c|c|c|}
\hline \multirow{3}{*}{ Karakteristik Subyek } & \multicolumn{6}{|c|}{$\begin{array}{l}\text { Variasi Kelompok Makanan Pendamping Air Susu } \\
\text { Ibu }\end{array}$} & \multirow{2}{*}{\multicolumn{2}{|c|}{$\sum$}} \\
\hline & \multicolumn{2}{|c|}{ Rendah } & \multicolumn{2}{|c|}{ Sedang } & \multicolumn{2}{|c|}{ Tinggi } & & \\
\hline & $\mathrm{n}$ & $\%$ & $\mathrm{n}$ & $\%$ & $\mathrm{n}$ & $\%$ & $\mathrm{n}$ & $\%$ \\
\hline \multicolumn{9}{|l|}{ Jenis Kelamin } \\
\hline Laki-laki & 21 & 21,4 & 51 & 52,0 & 26 & 26,5 & 98 & 100 \\
\hline Perempuan & 15 & 15,6 & 44 & 45,8 & 37 & 38,5 & 96 & 100 \\
\hline \multicolumn{9}{|l|}{ Usia anak (bln) } \\
\hline $6-8$ & 1 & 2,1 & 29 & 60,4 & 18 & 37,5 & 48 & 100 \\
\hline $9-11$ & 0 & 0 & 12 & 35,3 & 22 & 64,7 & 34 & 100 \\
\hline $12-23$ & 35 & 31,2 & 54 & 48,2 & 23 & 20,5 & 112 & 100 \\
\hline$\sum$ & 36 & 18,6 & 95 & 49,0 & 63 & 32,5 & 194 & 100 \\
\hline
\end{tabular}

Hasil penelitian menunjukkan bahwa penilaian yaitu banyaknya bahan variasi kelompok MP-ASI yang makanan yang dikonsumsi, konsumsi paling banyak adalah variasi sedang susu formula, dan konsumsi Air Susu yaitu $95(49,0 \%)$ anak. Variasi Ibu tersebut dipengaruhi oleh 3 atribut

Tabel 4. Variasi Kelompok Makanan Pendamping Air Susu Ibu berdasarkan Pendidikan dan Pekerjaan Ibu

\begin{tabular}{|c|c|c|c|c|c|c|c|c|}
\hline \multirow{4}{*}{ Karakteristik Responden } & \multirow{2}{*}{\multicolumn{6}{|c|}{$\begin{array}{c}\text { Variasi Kelompok Makanan Pendamping Air Susu } \\
\text { Ibu }\end{array}$}} & \multirow{3}{*}{\multicolumn{2}{|c|}{$\sum$}} \\
\hline & & & & & & & & \\
\hline & \multicolumn{2}{|c|}{ Rendah } & \multicolumn{2}{|c|}{ Sedang } & \multicolumn{2}{|c|}{ Tinggi } & & \\
\hline & $\mathrm{n}$ & $\%$ & $\mathrm{n}$ & $\%$ & $\mathrm{~N}$ & $\%$ & $\mathrm{n}$ & $\%$ \\
\hline \multicolumn{9}{|l|}{ Pendidikan Ibu } \\
\hline Dasar & 6 & 15,4 & 23 & 59,0 & 10 & 25,6 & 39 & 100 \\
\hline Menengah & 24 & 22,0 & 51 & 46,8 & 34 & 31,2 & 109 & 100 \\
\hline Tinggi & 6 & 13,0 & 21 & 45,7 & 19 & 41,3 & 46 & 100 \\
\hline \multicolumn{9}{|l|}{ Pekerjaan Ibu } \\
\hline Ibu Rumah Tangga & 27 & 18,1 & 77 & 51,7 & 45 & 30,2 & 149 & 100 \\
\hline Bekerja & 9 & 20,0 & 18 & 40,0 & 18 & 40,0 & 45 & 100 \\
\hline$\sum$ & 36 & 18,6 & 95 & 49,0 & 63 & 32,5 & 194 & 100 \\
\hline
\end{tabular}


Variasi makanan anak juga anaknya, terbukti dengan variasi dipengaruhi oleh ibunya, ibu yang yang beragam didapatkan dari ibu berpendidikan tinggi akan lebih tahu tentang makanan yang baik bagi berpendidikan tingkat atas yaitu 19 $(41,3 \%)$ ibu.

Tabel 5. Konsumsi Susu berdasarkan Kelompok Usia Subyek

\begin{tabular}{|c|c|c|c|c|c|c|c|c|c|c|}
\hline \multirow{3}{*}{$\begin{array}{l}\text { Kelompok Usia } \\
\text { (bln) }\end{array}$} & \multicolumn{8}{|c|}{ Konsumsi Susu } & & \\
\hline & \multicolumn{2}{|c|}{ ASI } & \multicolumn{2}{|c|}{$\begin{array}{l}\text { Susu } \\
\text { Formula }\end{array}$} & \multicolumn{2}{|c|}{$\begin{array}{l}\text { ASI dan } \\
\text { Susu } \\
\text { Formula }\end{array}$} & \multicolumn{2}{|c|}{$\begin{array}{c}\text { Tidak } \\
\text { Mengonsumsi }\end{array}$} & \multicolumn{2}{|c|}{$\Sigma$} \\
\hline & $\mathrm{n}$ & $\%$ & $\mathrm{n}$ & $\%$ & $\mathrm{n}$ & $\%$ & $\mathrm{n}$ & $\%$ & $\mathrm{n}$ & $\%$ \\
\hline $6-8$ & 31 & 64,6 & 1 & 2,1 & 16 & 33,3 & 0 & 0 & 48 & 100 \\
\hline $9-11$ & 27 & 79,4 & 0 & 0,0 & 7 & 20,6 & 0 & 0 & 34 & 100 \\
\hline $12-23$ & 58 & 51,8 & 19 & 17,0 & 33 & 29,5 & 2 & 1,8 & 112 & 100 \\
\hline$\sum$ & 116 & 59,8 & 20 & 10,3 & 56 & 28,9 & 2 & 1 & 194 & 100 \\
\hline
\end{tabular}

Konsumsi susu paling tinggi yaitu 11 bulan yaitu $27(79,4 \%)$ anak. konsumsi Air Susu Ibu saja yaitu Konsumsi susu formula paling sebanyak $116 \quad(59,8 \%)$ anak. banyak pada usia 12-23 bulan Konsumsi Air Susu Ibu saja paling sebanyak $19(17,0 \%)$ anak.

banyak ditemukan pada anak usia 9-

Tabel 6. Konsumsi Susu berdasarkan Pendidikan dan Pekerjaan Ibu

\begin{tabular}{|c|c|c|c|c|c|c|c|c|c|c|}
\hline \multirow{3}{*}{$\begin{array}{c}\text { Karakteristik } \\
\text { Responden }\end{array}$} & \multicolumn{8}{|c|}{ Konsumsi Susu } & & \\
\hline & \multicolumn{2}{|c|}{ ASI } & \multicolumn{2}{|c|}{$\begin{array}{l}\text { Susu } \\
\text { Formula }\end{array}$} & \multicolumn{2}{|c|}{$\begin{array}{l}\text { ASI dan } \\
\text { Susu } \\
\text { Formula }\end{array}$} & \multicolumn{2}{|c|}{$\begin{array}{c}\text { Tidak } \\
\text { Mengonsumsi }\end{array}$} & \multicolumn{2}{|c|}{$\sum$} \\
\hline & $\mathrm{n}$ & $\%$ & $\mathrm{n}$ & $\%$ & $\mathrm{n}$ & $\%$ & $\mathrm{n}$ & $\%$ & $\mathrm{n}$ & $\%$ \\
\hline \multicolumn{11}{|l|}{ Pendidikan Ibu } \\
\hline Dasar & 28 & 71,8 & 2 & 5,1 & 9 & 23,1 & 0 & 0,0 & 39 & 100 \\
\hline Menengah & 69 & 63,3 & 14 & 12,8 & 26 & 23,9 & 0 & 0,0 & 109 & 100 \\
\hline Tinggi & 19 & 41,3 & 4 & 8,7 & 21 & 45,7 & 2 & 4,3 & 46 & 100 \\
\hline \multicolumn{11}{|l|}{ Pekerjaan Ibu } \\
\hline Ibu RT & 100 & 67,1 & 15 & 10,1 & 34 & 22,8 & 0 & 0,0 & 149 & 100 \\
\hline Bekerja & 16 & 35,6 & 5 & 11,1 & 22 & 48,9 & 2 & 4,4 & 45 & 100 \\
\hline$\sum$ & 116 & 59,8 & 20 & 10,3 & 56 & 28,9 & 2 & 14,4 & 194 & 100 \\
\hline
\end{tabular}

Konsumsi susu dipengaruhi oleh pola asuh ibu. Konsumsi susu yang paling banyak adalah Air Susu Ibu baik dilihat dari pekerjaan dan pendidikan ibu. Jika dilihat dari pendidikan ibu yang paling banyak memberikan ASI adalah ibu dengan pendidikan dasar yaitu $28(71,8 \%)$ ibu.

Hasil penelitian menunjukkan bahwa variasi kelompok MP-ASI yang paling banyak adalah variasi sedang yaitu 95 (49,0\%) anak. Makanan Pendamping Air Susu Ibu (MP-ASI) 
adalah makanan lain yang diberikan pada balita usia 6-23 bulan sebagai pendamping Air Susu Ibu (ASI) (Agria dkk, 2012). Diusia 6 bulan, makanan bayi harus bervariasi, terutama dalam pemilihan bahan makanan. Pada saat ini sangat tepat bila bayi diperkenalkan dengan beragam bahan makanan seperti telur, daging sapi, ikan, hati ayam, udang, tempe, dan tahu. Demikian juga dengan kacang-kacangan dan sayuran. Pemberian MP-ASI diperuntukkan untuk memenuhi kebutuhan gizi selain ASI pada balita usia 6-23 bulan (Hayati, 2009).Variasi Makanan Pendamping Air Susu Ibu juga dipengaruhi oleh pendidikan dan pekerjaan ibu. Tingkat pendidikan berhubungan dengan status gizi karena dengan meningkatnya pendidikan kemungkinan akan meningkatkan pendapatan sehingga dapat meningkatkan daya beli makanan (Hartriyanti dan Triyanti, 2011).

Konsumsi bahan makanan hanya 2 macam saja belum cukup untuk memenuhi keanekaragaman makanan. Pada usia 6-23 bulan sebaiknya Air Susu Ibu tetap diberikan pada anak karena ASI masih mengandung zat gizi yang dibutuhkan anak walaupun zat gizinya hanya sedikit. Zat gizi yang kurang dari ASI bisa dipenuhi dengan adanya makanan tambahan yaitu Makanan Pendamping Air Susu Ibu.Asupan makanan anak usia 6-23 bulan selain dari bahan makanan ada juga susu. Susu yang dikonsumsi oleh anak adalah Air Susu Ibu dan susu formula. Hasil dari penelitian ini adalah anak yang banyak diberikan Air Susu Ibu saja adalah dari ibu dengan pendidikan dasar dan pekerjaan sebagai ibu rumah tangga. Lain halnya dengan ibu dengan pendidikan tinggi dan bekerja diluar rumah, ibu lebih banyak memberikan Air Susu Ibu dengan tambahan susu formula. Hal ini dikarenakan ibu yang bekerja tidak punya banyak waktu dirumah untuk memberikan ASI saja sehingga susu ditambah denga susu formula untuk mencukupi kebutuhannya.

Penelitian ini serupa dengan penelitian yang dilakukan oleh Charmaine dkk (2007) yang menganalisa tentang asupan makan balita berdasarkan kelompok makanan di Indonesia. Penelitian Charmaine mendapatkan hasil bahwa 
anak yang mengonsumsi 4 atau lebih dari kelompok bahan makanan yaitu sebesar $47,7 \%$ pada anak usia 6-11 bulan, $76,7 \%$ pada anak usia $12-17$ bulan, dan $84,2 \%$ pada anak usai 18 23 bulan.

Berdasarkan hal tersebut, sebaiknya dari kecil anak dibiasakan mengonsumsi makan alami dan pemberian ASI diteruskan hingga anak mencapai usia 23 bulan serta diusahakan tidak memberikan susu formula jika tidak dalam keadaan Tabel 7. Status Gizi dengan Indeks BB/U berdasarkan Jenis Kelamin dan Kelompok Usia

\begin{tabular}{|c|c|c|c|c|c|c|}
\hline \multirow{3}{*}{ Karakteristik Subyek } & \multicolumn{4}{|c|}{ Status Gizi (BB/U) } & \multirow{2}{*}{\multicolumn{2}{|c|}{$\sum$}} \\
\hline & \multicolumn{2}{|c|}{$\begin{array}{l}\text { Gizi Buruk dan Gizi } \\
\text { Kurang }\end{array}$} & \multicolumn{2}{|c|}{$\begin{array}{l}\text { Gizi Baik dan Gizi } \\
\text { Lebih }\end{array}$} & & \\
\hline & $\mathrm{N}$ & $\%$ & $\mathrm{n}$ & $\%$ & $\mathrm{~N}$ & $\%$ \\
\hline \multicolumn{7}{|l|}{ Jenis Kelamin } \\
\hline Laki-laki & 13 & 13,3 & 85 & 86,7 & 98 & 100 \\
\hline Perempuan & 12 & 12,5 & 84 & 87,5 & 96 & 100 \\
\hline \multicolumn{7}{|l|}{ Usia anak (bln) } \\
\hline $6-8$ & 2 & 4,2 & 46 & 95,8 & 48 & 100 \\
\hline $9-11$ & 2 & 5,9 & 32 & 94,1 & 34 & 100 \\
\hline $12-23$ & 21 & 18,8 & 91 & 81,2 & 112 & 100 \\
\hline$\sum$ & 25 & 12,9 & 169 & 87,1 & 194 & 100 \\
\hline
\end{tabular}

Berdasarkan Tabel 8.diketahui bahwa status gizi juga dipengaruhi oleh pendidikan dan pekerjaan ibu. Gizi buruk dan gizi kurang paling banyak pada ibu dengan pendidikan tingkat menengah yaitu $16(14,7 \%)$ dan pada Ibu Rumah Tangga yaitu 21 $(14,1 \%)$ ibu.

Hasil penelitian menunjukkan bahwa masih terdapat masalah gizi yaitu darurat. Pemberian ASI bersama dengan susu formula banyak dilakukan oleh ibu yang bekerja. Sebaiknya ibu yang bekerja menyediakan ASI perah agar bisa diberikan pada anak ketika ibu sedang tidak dirumah (bekerja).

\section{STATUS GIZI}

Status gizi yang digunakan pada penelitian ini adalah status gizi berdasarkan indeks BB/U. 
perubahan yang mendadak, misalnya terserang penyakit infeksi, menurunnya nafsu makan atau menurunnya jumlah makanan yang dikonsumsi(Kemenkes, 2010)

Penelitian ini serupa dengan penelitian Lestari (2014a) dengan yang menganalisa tentang pemberian susu formula dan status gizi di Semarang menyebutkan bahwa kelebihan konsumsi susu formula mengakibatkan gizi lebih sebesar $69,70 \%$, gizi kurang sebesar $24,24 \%$ dan gizi buruk sebesar 6,06\% .

Kurang cukupnya pangan untuk pertumbuhan maksimal, kesehatan, masalah gizi, dan kegiatan normal disebabkan oleh ketersediaan pangan. Ketersediaan pangan akan mempengaruhi jumlah asupan zat gizi yang masuk dalam tubuh yang akan berdampak pada status gizi (Andriani dan Bambang, 2012).Makin tinggi tingkat pendidikan, pengetahuan, dan keterampilan, maka makin baik tingkat ketahanan pangan keluarga (Agria dkk, 2012).Pendidikan yang rendah mengakibatkan ibu kesulitan dalam mendapatkan pekerjaan sehingga ibu menjadi ibu rumah tangga yang tidak bisa menambah penghasilan keluarga. Pendapatan yang minim dalam keluarga akan mengakibatkan ketersediaan makanan yang minim juga karena penghasilan dibagi untuk mencukupi kebutuhan lainnya.

Pola makan anak di Kecamatan Minggir masih kurang baik karena saat pengambilan data asupan makan, mayoritas anak makannya sedikit karena tidak nafsu makan. Sehingga anak yang tidak mendapat makanan yang cukup untuk memenuhi kebutuhannya maka akan meyebabkan $\mathrm{BB}$ rendah yang akan berpengaruh pada status gizinya. Berat badan rendah yang tidak sesuai dengan standart usianya maka akan menyebabkan masalah gizi yaitu gizi buruk dan gizi kurang.

\section{VARIASI KELOMPOK MAKANAN PENDAMPING AIR SUSU IBU DENGAN STATUS GIZI}

Keterkaitan antara variasi kelompok MP-ASI dengan status gizi berdasarkan indeks BB/U. 
Tabel 9. Keterkaitan Status Gizi dengan Variasi Kelompok Makanan Pendamping Air Susu Ibu

\begin{tabular}{|c|c|c|c|c|c|c|}
\hline \multirow{3}{*}{ Variasi Kelompok MP-ASI } & \multicolumn{4}{|c|}{ Status Gizi (BB/U) } & & \\
\hline & \multicolumn{2}{|c|}{$\begin{array}{l}\text { Gizi Buruk dan Gizi } \\
\text { Kurang }\end{array}$} & \multicolumn{2}{|c|}{$\begin{array}{c}\text { Gizi Baik dan Gizi } \\
\text { Lebih }\end{array}$} & \multicolumn{2}{|c|}{$\sum$} \\
\hline & $\mathrm{n}$ & $\%$ & $\mathrm{n}$ & $\%$ & $\mathrm{n}$ & $\%$ \\
\hline Rendah & 8 & 22,2 & 28 & 77,8 & 36 & 100 \\
\hline Sedang & 8 & 8,4 & 87 & 91,6 & 95 & 100 \\
\hline Tinggi & 9 & 14,3 & 54 & 85,7 & 63 & 100 \\
\hline$\sum$ & 25 & 12,9 & 169 & 87,1 & 194 & 100 \\
\hline
\end{tabular}

Hasil penelitian menunjukkan bahwa anak yang memiliki status gizi buruk dan gizi kurang dengan variasi MPASI rendah ada $8(22,2 \%)$ anak, variasi MP-ASI sedang ada $8(8,4 \%)$ anak, dan variasi MP-ASI tinggi ada $9(14,3 \%)$ anak

Hasil penelitian menunjukkan bahwa anak yang memiliki status gizi buruk dan gizi kurang dengan variasi MPASI rendah ada $8(22,2 \%)$ anak, variasi MP-ASI sedang ada $8(8,4 \%)$ anak, dan variasi MP-ASI tinggi ada $9(14,3 \%)$ anak.

Penelitian antara MP-ASI dengan status gizi yang dilakukan oleh Lestari (2012) di Padang menyatakan bahwa masih terdapat masalah gizi yaitu $104(52 \%)$ anak memiliki status gizi baik dan 96 (48\%) anak memiliki status gizi kurang Lestari, 2014b)

Menurut Andersen (1987) dalam Aritonang (2012) status gizi dipengaruhi oleh dua hal utama yaitu makanan yang dikonsumsi dan

derajat kesehatan. Variasi MP-ASI

dapat mempengaruhi asupan makan yang pada akhirnya akan berpengaruh pada status gizi.Status gizi dan asupan saling terkait, sehingga untuk mendapatkan status gizi yang baik maka asupan makan yang masuk harus sesuai dengan kebutuhan dan bahan makanan yang digunakan seimbang agar zat gizi dapat dipenuhi dari berbagai macam bahan makanan.

\section{KESIMPULAN}

1. Variasi kelompok Makanan Pendamping Air Susu Ibu paling banyak yaitu variasi kelompok MPASI sedang yaitu $22(64,7 \%)$ pada anak usia 9-11 bulan.

2. Sejumlah $25(12,9 \%)$ anak usia 6-23 bulan mengalami gizi buruk dan gizi kurang.

3. Semakin rendah variasi Makanan Pendamping Air Susu Ibu maka semakin tinggi persentase gizi buruk dan gizi kurang. 


\section{SARAN}

1. Bagi Peneliti Selanjutnya

Penilaian variasi MP-ASI bisa dilakukan menggunakan 2 metode yaitu metode recall 24 jam yang lalu dan food frequency. Pada penelitian ini menggunakan metode recall 24 jam yang lalu sebanyak 2 kali. Untuk penelitian selanjutnya bisa mencoba menggunakan metode food frequency

\section{Bagi Puskesmas Minggir}

Variasi Makanan Pendamping Air Susu Ibu dipengaruhi oleh banyaknya konsumsi bahan makanan serta konsumsi ASI dan susu formula. Konsumsi ASI dan susu formula paling banyak ditemukan pada ibu yang bekerja. Berdasarkan hal tersebut, ahli gizi diharapkan memberikan pengarahan kepada ibu untuk menyediakan ASI perah saat ibu bekerja diluar rumah. Pengarahan dilakukan dengan menyebarkan leaflet manajemen pemberian ASI perah kepada ibu bekerja yang memiliki anak usia 6-23 serta menyediakan poster tentang ASI eksklusif di tempat kerja agar ibu selalu ingat dengan pemberian ASI eksklusif.

\section{DAFTAR PUSTAKA}

Adriani M, dan Bambang W. 2012. Pengantar Gizi Masyarakat. Jakarta: Kencana Prenada Media Group.

Agria I, Ruri N, dan Ircham. 2012. Gizi Reproduksi. Yogyakarta: Fitramaya.

Aritonang I. 2012. Menilai Status Gizi untuk Mencapai Sehat Optimal. Yogyakarta: Leutikabooks dengan CEBioS.

Charmaine, Michael JD, Kingsley EA. Complementary feeding indicators and determinants of poor feeding practices in Indonesia: a secondary analysis of 2007 Demographic and Health Survey data. Public Health Nutrition. 2007:15(5):827839.

Dinas Kesehatan Sleman. 2014. Penilaian Status Gizi di Masing-Masing Kecamatan Berdasarkan Indeks BB/U, $\mathrm{PB}(\mathrm{TB}) / \mathrm{U}$, BB/TB Kabupaten Sleman DIY Tahun 2014.

Hayati AW. 2009. Buku Saku Gizi Bayi. Jakarta:ECG.

Istiany A, dan Rusilanti. 2013. Gizi Terapan. Bandung: PT Remaja Rosdakarya.

Hartriyanti Y, dan Triyanti. 2011. Gizi dan Kesehatan Mayarakat. Jakarta: Departemen Gizi dan Kesehatan Masyarakat Fakultas Kesehatan Masyarakat Universitas Indonesia.

Kementerian Kesehatan. 2010. Pelatihan Konseling Makanan Pendamping Air Susu Ibu. Jakarta: Direktorat Bina Gizi Masyarakat.

Kementerian Kesehatan RI. 2013. Riset Kesehatan Dasar 2013. Jakarta: Badan Penelitian Dan Pengembangan Kesehatan Kementerian Kesehatan RI.

Lestari P, Suyatno, Apoina Kartini. 2014a. Hubungan Praktik Pemberian Susu Formula Dengan Status Gizi Bayi Usia 0-6 Bulan Di Kecamatan Semarang Timur Kota Semarang. Jurnal Kesehatan Masyarakat. II(6):339-47.

Lestari MU, Gustina Lubis, Dian Pertiwi. 2014b. Hubungan Pemberian Makanan Pendamping Asi (MP-ASI) dengan Status 
Gizi Anak Usia 1-3 Tahun di Kota Padang Tahun 2012. Jurnal Kesehatan Andalas. 3(2):188-190

Proverawati, Atikah., dan Erna Kusuma Wati. 2010. Ilmu Gizi untuk Keperawatan dan Gizi Kesehatan. Yogyakarta: Nuha Medika.
Siti NR, Hikmawati M, Jayanti G. Studi Pemberian MP-ASI Dini dan Status Gizi Bayi Umur 0-6 Bulan di Kelurahan Botang Kecamatan Makale Kabupaten Tana Roja. Media Gizi Pangan. 2013; edisi 1:XV:77-83 